\title{
Lumen
}

Selected Proceedings from the Canadian Society for Eighteenth-Century Studies

Travaux choisis de la Société canadienne d'étude du dix-huitième siècle

\section{The Cosmic Sublime: Wright of Derby's A Philosopher Lecturing on the Orrery}

\section{Jesse Molesworth}

Volume 34, 2015

URI : https://id.erudit.org/iderudit/1028514ar

DOI : https://doi.org/10.7202/1028514ar

Aller au sommaire du numéro

Éditeur(s)

Canadian Society for Eighteenth-Century Studies / Société canadienne d'étude du dix-huitième siècle

ISSN

1209-3696 (imprimé)

1927-8284 (numérique)

Découvrir la revue

Citer cet article

Molesworth, J. (2015). The Cosmic Sublime: Wright of Derby's A Philosopher Lecturing on the Orrery. Lumen, 34, 109-121. https://doi.org/10.7202/1028514ar d'utilisation que vous pouvez consulter en ligne. 


\title{
The Cosmic Sublime: Wright of Derby's A Philosopher Lecturing on the Orrery
}

\author{
Jesse Molesworth \\ Indiana University
}

In July 1764 the Scottish scientist James Ferguson offered series of lectures on the physical sciences, including mechanics, hydrostatics, pneumatics, and astronomy, in County-Hall in the city of Derby. ${ }^{1}$ The lectures themselves were not notable; they were several of many such lectures offered by Ferguson between 1748 and his death in 1776 . What is notable about the occasion is the prospect that has tantalized many an art historian: that one of Ferguson's lectures was visited by Joseph Wright of Derby, who two years later would exhibit the painting A Philosopher giving That Lecture on the Orrery, in which a Lamp is Placed in the Position of the Sun (1766, figure 1). ${ }^{2}$

The appeal of viewing the painting as referencing this event, and viewing Wright's white-haired philosopher as Ferguson, is obvious. It connects Wright's work to a tradition of scientific painting exemplified

1. See Derby Mercury, vol. xxxiii, no. 5 (6-13 April 1764), 4.

2. David Fraser, for example, writes the following in support of the Ferguson attribution: "It does appear highly likely that Wright had the opportunity to witness personally a lecture on the orrery, like that depicted in his painting, given in Derby in 1762 by Whitehurst's friend and correspondent the Scottish astronomer James Ferguson." Fraser here misprints the date as 1762 , rather than 1764 , perhaps following the same misprint by Benedict Nicolson. See also Elizabeth E. Barker's interesting suggestion that the model may have been James Arden, a travelling philosopher who gave a series of lectures on astronomy in 1762. See David Fraser, "Joseph Wright of Derby and the Lunar Society," in Judy Egerton (ed.), Wright of Derby (London: Tate Gallery Publications, 1990), 15-24, at 16; Nicolson, Joseph Wright of Derby: Painter of Light, 2 vols. (London, 1968), 114-15; Barker, "New Light on The Orrery: Joseph Wright and the representation of astronomy in eighteenth-century Britain," The British Art Journal vol. 1, no. 2 (Spring 2000), 29-37. 


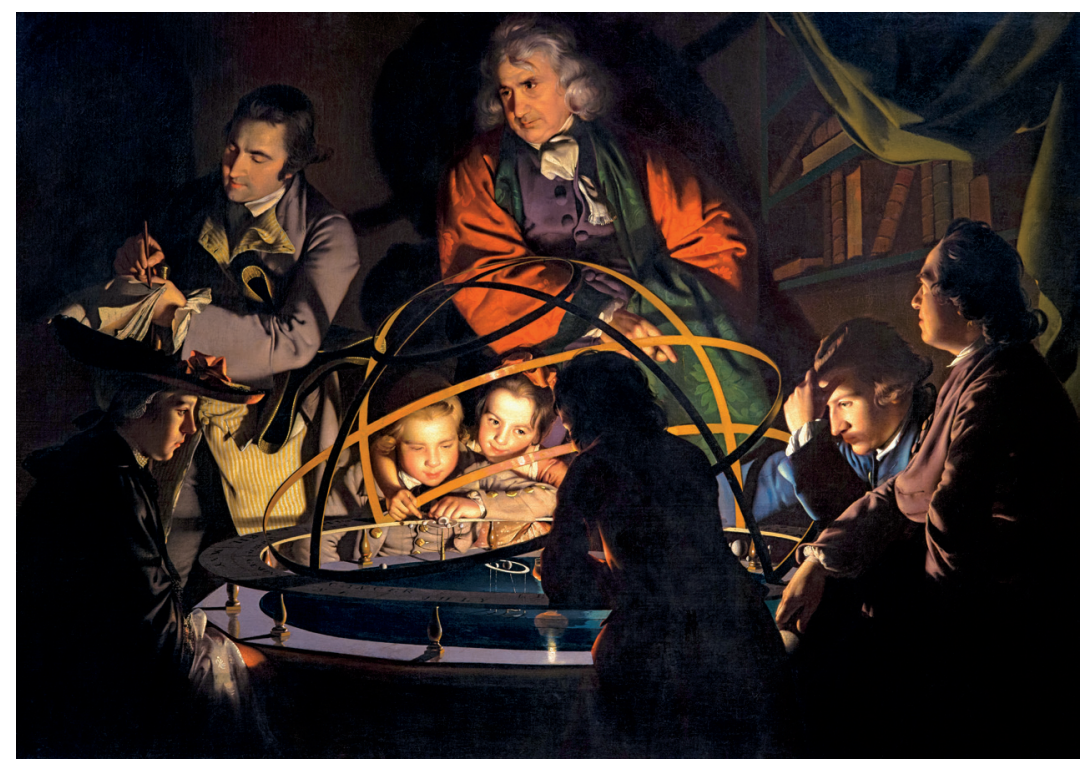

Figure 1. Joseph Wright of Derby, A Philosopher giving That Lecture on the Orrery, in which a Lamp is Placed in the Position of the Sun (1766). (C) 2014 Derby Museums Trust.

by Rembrandt's The Anatomy Lesson of Dr. Nicholaes Tulp (1632). ${ }^{3}$ It equally connects the painting to Wright's other scientifically themed works, especially An Experiment on a Bird in the Air Pump (1768) and The Alchymist (1770), the triad of midcentury works said to celebrate rational enquiry, progress, and the values of the Lunar Society (to which Wright was informally connected). According to the essay prefacing the most extensive compilation of Wright's paintings, it is a "painting representative of Enlightenment philosophy," wherein the lamp, a manmade mechanism, has come to replace divine light as the central source of illumination. ${ }^{4}$ Perhaps for these reasons it has become

3. See Rose-Marie and Rainer Hagen, What Great Paintings Say (New York: Taschen, 2000), 327 .

4. David Fraser, "Joseph Wright of Derby and the Lunar Society," in Judy Egerton (ed.), Wright of Derby, 18. Ronald Paulson offers a useful summary of the traditional view of Wright as an empiricist and proto-Marxist industrialist in Breaking and Remaking: Aesthetic Practice in England, 1700-1820 (New Brunswick, NJ: Rutgers University Press, 1989), 203-6. This view has been significantly extended by 
equally popular to view the philosopher as a latter-day avatar of the similarly white-haired Isaac Newton, lecturing on the vision of the cosmos that he helped to create. Viewed this way, the painting offers a visual representation of the lines by Pope intended for Newton's epitaph: "Nature and Nature's laws lay hid in night / God said, Let Newton be, and all was light."

Thus, the eternal question: Newton, Ferguson, or neither? As has occasionally been noted, viewing the painting as an actual event, with the philosopher as Ferguson, introduces a host of problems. First of all, Ferguson almost certainly would not have used the type of orrery-the hulking central contraption illustrating the movements of the planets-illustrated within the painting. As an itinerant lecturer, Ferguson generally favored more portable models. Whether or not Ferguson would have used a decorative armillary sphere encircling the orrerysurely one of the painting's most arresting features - remains dubious. As Elizabeth E. Barker has discussed, Wright's orrery is grander, more expensive, and older than those constructed in the 176os; it may be that Wright modeled it on one possessed by Lord Ferrers (who would

David H. Solkin, who discusses the Orrery and the Air Pump within the context of the rise of the bourgeois public sphere, and by Andrew Graciano, who reads of Wright's landscape paintings within the context of geological science and the Derby Philosophical Society. See Solkin, Painting for Money: The Visual Arts and the Public Sphere in Eighteenth-Century England (New Haven, CT: Yale University Press, 1992), 214-46; Graciano, Joseph Wright, Esq., Painter and Gentleman (Newcastle upon Tyne: Cambridge Scholars Publishing, 2012), 1-30.

5. Egerton, for example, writes the following in support of the Newton attribution:

Newton's theory of the universe provided the foundation for demonstrations such as this; he was not only celebrated among his peers but revered by every Philosophical Society in England. Wright has not tried to copy a portrait of Newtonhis scene after all is set in his own day and Newton died in 1727-but he certainly seems to have looked at portraits of Newton in search of the ideal image of a philosopher. Wright's philosopher most clearly resembled Kneller's portrait of Newton of 1689, in a private collection; though that portrait was not engraved, it is known to have been widely copied. Wright may also have looked at the portrait by Vanderbank engraved for Newton's Mathematica Principia, 1726.

See Egerton (ed.), Wright of Derby, 54-55. Wright frequently made reference to leading intellectuals within his works. The foregrounded man timing the experiment within the Air Pump, for example, is often said to represent Erasmus Darwin, while Stephen Leach and Simon Manby have interestingly suggested that the philosopher in A Philosopher by Lamplight (1769) may allude to Rousseau. See Leach and Manby, "Jean-Jacques Rousseau and Wright's Philosopher by Lamplight," British Art Journal, vol. XIII, no. 1 (2012): 37-45. 
eventually purchase the painting and has often been proposed as its original commissioner), or on Thomas Wright's "Great Orrery," whose image was widely known in Wright's day. ${ }^{6}$ Whatever the case, lecturers like Ferguson and his colleague Benjamin Martin sponsored a turn away from the traditional ornamentation of models of the cosmos. As Martin would write, only years later in 1771, "the Orrery I propose is a bare Representation of the Solar System in its native Simplicity, and is, in its self, sufficiently grand, and pompous; it stands in Need of none of the useless, expensive, and cumbersome Embellishments of Art." ${ }^{7}$ Indeed, figures like Ferguson and Martin helped to transform the orrery from princely luxury to bourgeois acquirement. Within two decades of Ferguson's Derby lecture, a working orrery would cost little more than two pounds; those manufactured by the ingenious entrepreneur William Jones came in pieces in a wooden box, to be assembled by its purchaser much in the manner of an Ikea bookshelf. ${ }^{8}$

The presence of such features would seem to abstract the scene out of 1764 and the event of Ferguson's Derby lecture (assuming that Wright even witnessed it). The armillary sphere, that is, points not to Ferguson but to traditional illustrations of the astronomer, such as those recently catalogued in the Hertel edition (1758-60) of Cesare Ripa's Iconologia. Thus, the armillary sphere stands less as a thing or device possessed by the astronomer and more as a metonym for astronomy itself (Figure 2).

In referencing such emblematic portrayals, Wright's painting analogizes several related shifts: from classical to contemporary garb, from Ptolomaic to Copernican cosmos, and from the timeless (allegory) to

6. See Barker, "New Light," esp. 29-32.

7. See Martin, The Description and Use of an Orrery of a New Construction (London: 1771), 11-12.

8. See William Jones, The Description and Use of a New Portable Orrery (London, 1787), 43. Other orreries could be assembled using pasteboard, scissors, and pinswhich when properly put together would yield, according to one advertisement, "an exceeding good manual Orrery, that will show you as much as those usually sold for 2£. 12s. 6d." See G. Wright, The Description and Use of Both the Globes, the Armillary Sphere, and Orrery (London, 1783), 97. On the historical development of the orrery, see especially Henry C. King, Geared to the Stars: The Evolution of Planetariums, Orreries, and Astronomical Clocks (Toronto and Buffalo: University of Toronto Press, 1978), esp. 150-67; see also John R. Millburn, "Benjamin Martin and the Development of the Orrery," The British Journal for the History of Science, Vol. 6, No. 4 (Dec., 1973), 378-99. 


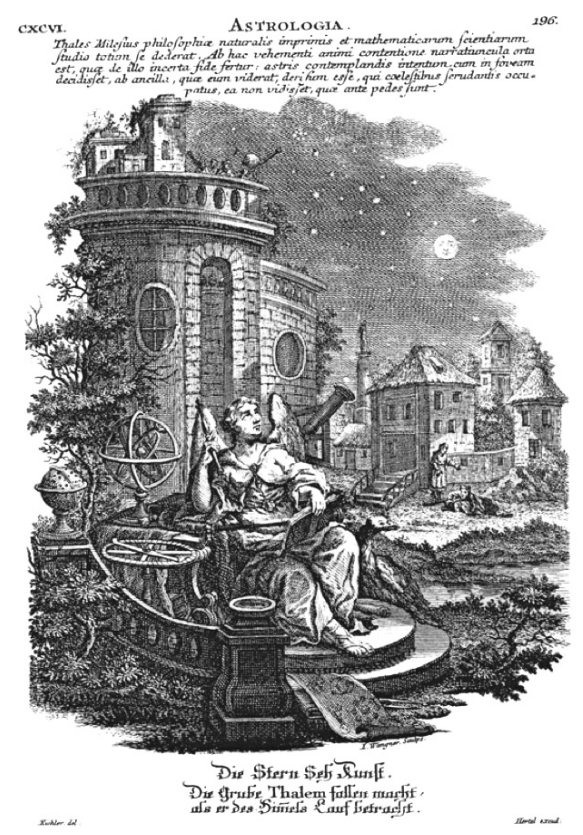

Figure 2. Cesare Ripa, "Astrologia," from the 1758-6o Hertel edition of Ripa's Iconologia (Cesare Ripa, Baroque and Rococo Pictorial Imagery, trans. Edward A. Maser, New York: Dover Publications, 1971). Reproduced with permission from Dover Publications.

the temporary (tableau). As Ripa's astrologer gazes up and at the Heavens, Wright's philosopher gazes down and at his assembled audience-precisely away from the Heavens-as though to suggest nothing less than the radical recentering of the cosmos implied by the orrery.

Understanding the painting in this way, within Ronald Paulson's movement from emblem to expression, holds a great deal of appeal. ${ }^{9}$ But it also invites a related question: what exactly is the work intended to express? The most persuasive answer to this question has come recently from Paul Duro, who sees Wright's painting as visualizing a version of the midcentury sublime. As Duro shows, the cosmos had long served a privileged topic within discussions of sublimity. Joseph Addison, for example, offered the following words about the Newtonian cosmos in his essays on the pleasures of the imagination (1712): "when

9. Paulson, Emblem and Expression: Meaning in English Art of the Eighteenth Century (Cambridge: Harvard University Press, 1975). 
we survey the whole Earth at once, and the several Planets that lye within its Neighborhood, we are filled with a pleasing Astonishment, to see so many Worlds, hanging one above another, and sliding round their Axles in such an amazing Pomp and Solemnity." ${ }^{10}$ Wright's contemporary, Edmund Burke, wrote memorably on the same topic within the section on "Magnificence" in his Philosophical Enquiry into our Ideas of the Sublime and the Beautiful (1757): "The starry heaven, though it occurs so frequently to our view, never fails to excite an idea of grandeur."ll Meanwhile, Immanuel Kant, the other great eighteenth-century theorist of the sublime, would write similarly within his youthful treatise Universal Natural History and Theory of the Heavens (1755): "the magnitude of a planetary system in which the Earth is as a grain of sand and scarcely noticeable" when compared with "the infinite multitude of worlds and systems that constitute the sum total of the Milky Way."12 In the way that Wright's other paintings confront the viewer with big questions - the nature of matter in The Alchymist and the reality of death in the Air Pump-The Orrery, so Duro argues, confronts the viewer with the sublimity of infinitude. ${ }^{13}$

Yet in certain ways the painting itself defeats this view. For the orrery represents not the vast cosmos nor even the "starry heaven" but, rather, the world system as it was known in Wright's day, up to and including Saturn and its moons. Burke's "grandeur" and Kant's "magnitude" seem, if anything, notable in their absence from Wright's painting. The represented planets-Saturn and its moons to the left of the shadowed figure, the Earth and the moon to the right-are miniscule rather than magnificent, dwarfed as they are by the enormous armillary sphere. Indeed, the planets look as though little more than trinkets next to the two clustered children, whose heads float by hap-

10. Addison, Joseph, Spectator 420, in The Works of Joseph Addison, ed. George Washington Greene, 6 vols. (New York, 1854), VI: 366-69; at 367. Subsequent citations refer to this edition.

11. Burke, Philosophical Enquiry, ed. James T. Boulton (Notre Dame and London: University of Notre Dame Press, 1958), 78.

12. Kant, Universal History and Theory of the Heavens, in Natural Science, ed. Eric Watkins, trans. Lewis White Beck, et. al. (Cambridge University Press, 2012), 222.

13. Duro, "'Great and Noble Ideas of the Moral Kind': Wright of Derby and the Scientific Sublime," Art History 33.4 (September 2010): 660-79. See also another recent consideration of Wright's connection to the sublime in Stephen Leach, "The Lightning Rod Controversy and Antigonus in the Storm by Joseph Wright of Derby (1734-97)," The British Art Journal vol. XIV, no. 3 (2013): 75-78. 
pily, almost like planets in their own right. ${ }^{14}$ Rather than representing human smallness, the painting curiously reverses this theme, staging enormity (the planets) through relative obscurity, and reconfiguring smallness (the children) as centrality. To put it more bluntly, the painting operates through contradiction, wherein bigness represents smallness, smallness represents bigness, and delicacy comes to stand for profundity.

One might of course suggest that such contradictions are rooted in Wright's longstanding interest in establishing binary oppositions within his paintings. Within the Air Pump, for example, the central spectacle, featuring a white cockatoo gradually expiring within a vacuum, establishes a stark contrast between life and death. Meanwhile the various responses of those viewing the event might be said to juxtapose rationality with passion, which seems strongly coded within the painting as masculine versus feminine (see Figure 3). ${ }^{15}$

In the Orrery, however, such binary oppositions are raised for the purposes of questioning them, or even harmonizing them. The assumed contrast of man-made light (a lamp) versus divine light (God) or cosmic light (the Sun) seems mitigated, or even disguised, by Wright's startling strategy of obscuring the central light source behind the shadowed figure in the foreground. Does the lamp illuminate, as it does to the two children, whose warm embrace seems further warmed by the makeshift Sun? Or does the lamp bring darkness, as it does to the shadowed figure, another child, whose intervening body eclipses the viewer's sight of the lamp? The answer, so the painting suggests, is that it depends on where you are standing.

Like the Air Pump, the Orrery therefore offers two dominant responses to the central object: the bemused smiles of the two children and the pensive, perhaps even bewildered, gazes of the young man and the young woman to either side of the apparatus. Represented visually, it stages the view from inside the armillary sphere versus the view from outside. But the turn to age rather than gender as the dividing line between the two responses invites the inevitability that those inside will, some day, move outside. In contrast to the Air Pump, one might therefore read the Orrery as a Bildungsroman, narrative in character,

14. I thank Srinivas Aravamudan for this observation.

15. For more on such binaries, see Duro, "Great and Noble Ideas," 676. 


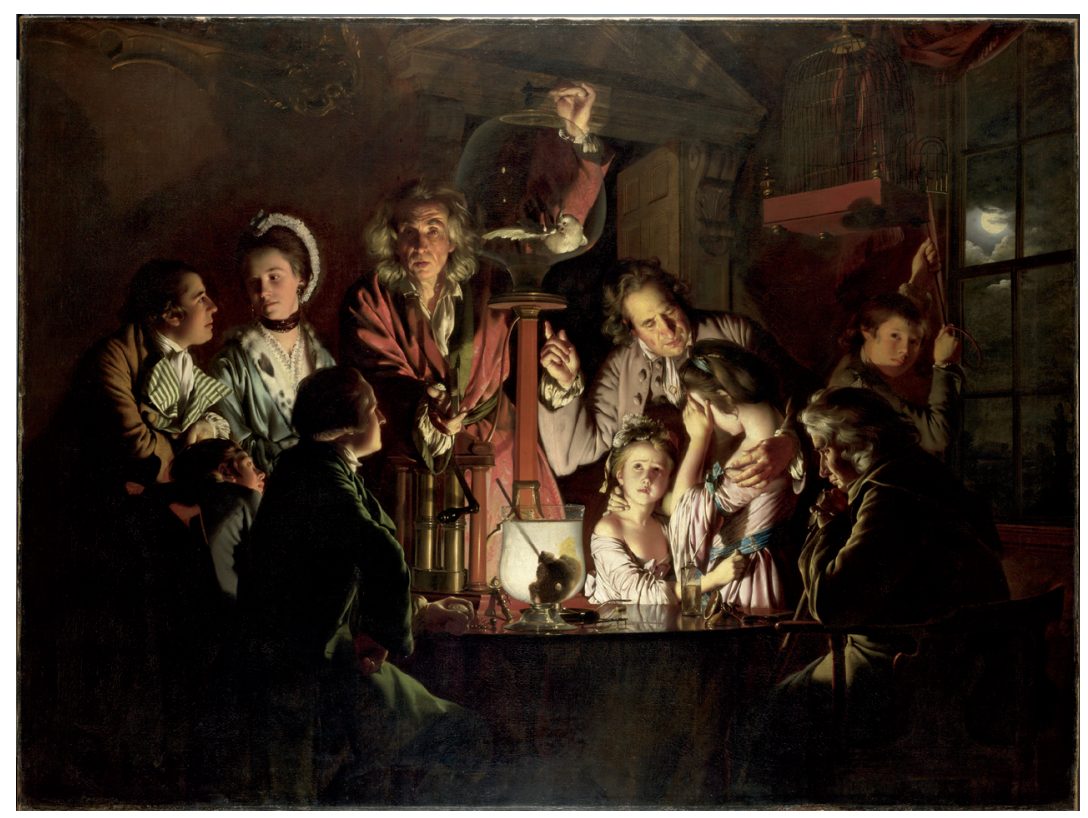

Figure 3. Joseph Wright of Derby, An Experiment on a Bird in the Air Pump (1768), presented by Edward Tyrrell, 1863. (C) The National Gallery, London.

in which the children are identical to the young man and the young women. Thus, the painting stages the passage of generations through gradually expanding fields, from youth (the three children: two illuminated, one shaded) to adulthood (the young woman and young man) to maturity (the two other male onlookers) to old age (the philosopher). This passage is understood first through the recognition of human smallness, as the tender familial bond of the two children gives way later to the contemplative look of the young man and the distant look of the young woman, and later to the more self-assured expression of the philosopher, which suggests acceptance or even mastery of this idea. The point is that while the Orrery holds several responses, it does not hold them apart. Rather, each response is seen as predicated on and constituted by prior responses.

One by one, then, Wright introduces a series of binaries (dark/light, small/large, child/adult) only to erode them, or to question the grounds by which they are established. But this is perhaps appropriate for a 
painting that simultaneously erodes one of the most cherished binaries within eighteenth-century aesthetics: the distinction between the sublime and the beautiful. Recall that for Addison the distinction between these two was as plain as the difference between Homer and Virgil. Homer, so Addison wrote, startles the reader with greatness and, through it, sublimity: "Reading the Iliad is like travelling through a country uninhabited, where the fancy is entertained with a thousand savage prospects of vast deserts, wide uncultivated marshes, huge forests, misshapen rocks and precipices." Whereas Virgil offers an irreconcilably different aesthetic: "the Aeneid is like a well ordered garden, where it is impossible to find out any part unadorned, or to cast our eyes upon a single spot, that does not produce some beautiful flower or plant." ${ }^{6}$ Burke departed from Addison in emphasizing sensation over content, with pain producing sublimity and pleasure producing beauty. Still, this shift in focus left the division of the two largely intact. Stronger still, it was reinforced: "the ideas of the sublime and the beautiful stand on foundations so different, that it is hard, I had almost said impossible, to think of reconciling them in the same subject, without considerably lessening the effect of the one or the other upon the passions." 17 Yet there it is, within Wright's painting: the marriage of sublimity and beauty. On the one hand, there is the pained expression of the young man, who grasps the orrery as a metaphor for infinity and, therefore, infinite smallness. On the other hand, there is the pleasure of the children, who view the orrery as object rather than as metaphor, and who consequently gaze on it with admiration and bemusement instead of awe. If the young man seems as though borrowed from a Caravaggio painting, dark and brooding, such angelic children seem plucked from a Raphael, and Wright's characteristic tenebrism all but washes away in their presence. To put it slightly differently, the young man dwells in a world described by Burkean Obscurity: "dark, uncertain, confused, terrible, and sublime to the last degree” (59). Wright's children, though, seem captivated by what Burke might have described as the Grace of the instrument: "this ease, this roundness, this delicacy of attitude and motion" (119). ${ }^{18}$

16. Addison, Spectator 417, in Works VI: $352-57$; at 354.

17. Burke, Philosophical Enquiry, 114.

18. In certain ways, then, Wright's blending of beauty and sublimity seems closer in spirit to Hogarth's attempt to reconcile the two. Ronald Paulson has written 
Such ambivalence, moreover, reflects more broadly held assumptions about the cosmos in Wright's day. Against Duro's claim that the cosmos served as a privileged site for the representation of sublimity, one might advance precisely the opposite claim: that the cosmos yoked together concepts of beauty and sublimity like no other object of enquiry within the eighteenth century. Kant, for example, offers a wealth of observations about the cosmos in his Universal Natural History and Theory of the Heavens, only some of which have to do with its grandeur and magnificence. He also remarks, for example, on its "skilful arrangements directed to a worthy purpose," while later affirming that "order and beauty shine forth in the constitution of the world." 19 The infinitude of the cosmos ultimately makes it infinitely flexible. As Kant concludes his remarks in one section: "It is precisely the same unlimited fertility of nature that has brought forth the inhabited heavenly spheres as well as the comets, the useful mountains and the harmful cliffs, habitable landscapes and empty deserts, virtues and vices." ${ }^{20}$ And so, one thinks, the unlimited fertility of the cosmos likewise brings forth the otherwise opposed dyad of beauty and sublimity.

Wright's painting is ultimately misclassified as a scientific painting, for the reason that the orrery, as a model of the cosmos, is not really a scientific instrument. When the chemist Joseph Priestley compared the orrery to a "work of fiction," offering entertainment rather than instruction (unlike more sophisticated scientific instruments like the air pump, which was closer to "real history") he was expressing a longstanding scientific distrust of the orrery. ${ }^{21}$ On the one hand, orreries introduced countless numbers to the elementary workings of the cosmos and to the reality of the Copernican world-system, through endeavors like Ferguson's. But, on the other hand, the project of representing such vastness with any degree of accuracy produced inevitable distortions. More than one astronomer would share John F. W. Herschel's view of orreries as "very childish toys," which rendered

authoritatively on this topic: "Hogarth took the active aggressiveness of the sublime and combined it with the undulating form of the beautiful and called it beauty." See Paulson, Breaking and Remaking: Aesthetic Practice in England, 1700-1820 (New Brunswick, NJ: Rutgers University Press, 1989), 198.

19. Kant, Universal Natural History, 291, 292.

20. Kant, Universal Natural History, 293.

21. Cited in Jenny Uglow, The Lunar Men: Five Friends Whose Curiosity Changed the World (New York: Ferrar, Straus, and Giroux, 2002), 77 
the Sun too small, the Earth and smaller planets too large, and the orbits of the planets too circular. ${ }^{22}$ More than simply representing a working orrery, then, Wright's painting captures some of its contradictions within eighteenth-century life. Wright would of course be long dead by the time of Herschel's snarling dismissal, but one nevertheless feels the force of it within the painting, which stages the orrery precisely as a childish toy. Like any number of related instruments and phenomena-Vaucanson's automata, Hans Sloane's meticulously catalogued collection of curiosities, magic lantern shows and other phantasmagoria-the orrery stood, perhaps occasionally uncomfortably, at the intersection of science and art, or within what Barbara Stafford describes as the field of "artful science." ${ }^{23}$ By including the armillary sphere, Wright suggests the liminal status of the orrery, neither fish nor fowl. The armillary sphere is beautiful but ultimately unnecessary - and that is the point. If the moving parts of the orrery serve to represent the purposiveness of nature-the divine design of the cosmos-the armillary sphere stands, by contrast, as the visual expression of Kant's soon to be famous definition of beauty as purposiveness without purpose. ${ }^{24}$

All this is admittedly quite a bit for one painting to represent, but I propose that such ideas underwrite the question posed at the outset of this essay: does the philosopher depict Newton or Ferguson? Surely it depicts both. As Ferguson, the philosopher introduces his audience to the boundlessness of the cosmos, which overwhelms by referencing infinity. As Newton, the philosopher contrarily emphasizes the harmony and compactness of our own world-system, which comforts by referencing design. For such were the twin faces of the cosmos within the eighteenth century: infinity balanced with and against design.

I wish to conclude these remarks on the orrery and the cosmos by fast-forwarding several decades to Maria Edgeworth's children's story

22. Herschel, A Treatise on Astronomy (London, 1833), 287.

23. Stafford describes the various "mathematical recreations" and "philosophical entertainments," such as Ferguson's lectures, as "exciting ways of doing science by stimulating the eyes." See Stafford, Artful Science: Enlightenment Entertainment and the Eclipse of Visual Education (Cambridge, MA: MIT Press, 1999), xxi.

24. As Kant writes, "Beauty is the form of the purposiveness of an object, insofar as it is perceived in it without representation of an end." See Kant, Critique of the Power of Judgment, ed. Paul Guyer, trans. Paul Guyer and Eric Matthews (Cambridge University Press, 2000), 120. 
Frank, A Sequel to Frank in Early Lessons (1822). The story follows Frank, a precocious young boy who is inspired to the study of astronomy after viewing a performance of the Eidouranion, a London stage spectacle popular in the decades following William Herschel's epochal discovery of Uranus in 1781. The centerpiece of the Eidouranion was a gigantic orrery, advertised variously as fifteen feet, twenty feet and ultimately twenty-four feet in diameter, and illustrating the movements of the planets and other heavenly bodies through a complex system of illumination and back projection. A contemporary newspaper touted its program thus: "it exhibits the diurnal and annual motions of every planet, and satellite in the solar system, without any apparent cause or support. Day, night, twilight, winter, summer, long and short days; the waxing and waning of the moon; solar and lunar eclipses; the causes of the tides; the transit of Venus and Mercury; and the descent of a comet, are so like nature, that a bare inspection of the machine gives the clearest idea of these phenomena." ${ }^{25}$

One scene within Edgeworth's story finds Frank and his sister Mary gazing up at the night sky and reflecting on the spectacle offered by the Eidouranion:

it was a fine clear frosty night, and she stood perfectly still and silent, enjoying the feeling of the fresh air, and the sight of the moon, the blue sky, and the innumerable blue stars.

"Mary," said Frank, "only think of that moon's being another world!"

"I do not know how to imagine it," said Mary.

"But it is really so," said Frank: "and all these stars are worlds! How wonderful! What is the orrery compared to this, Mary!" said Frank in a serious tone. "How grand! How different than any thing that the most ingenious man in this world can make!"26

Frank's response therefore consolidates the version of cosmic sublimity we have seen, by emphasizing grandeur and unrepresentability. The scene offers a moment of crisis for the young boy, one suggesting not merely the inadequacy of his own individual impressions but also, more largely, the inadequacy of human imagination itself. With reference to Wright's painting, Frank here navigates from inside the orrery

25. Cited in Richard D. Altick, The Shows of London (Cambridge, MA and London: The Belknap Press of Harvard University Press, 1978), 81.

26. Maria Edgeworth, Frank, A Sequel to Frank in Early Lessons, vol. 1 of 2 (Boston, 1861),307. 
to outside, from child to adult, by seeing not what the orrery can represent, but precisely what it cannot.

His sister Mary, though, offers a different response to the same sight: “'How beautiful!' said she; 'and how-' sublime! she would have said, but she did not know the word well enough; she knew the feeling" (306). Beauty and sublimity, the expressible and the inexpressible, thus co-exist happily within Mary's reply. It is a feeling_of simultaneously knowing and not knowing-that surely greeted many who gazed on Wright's painting, on Ferguson's orreries, and on the cosmos during the eighteenth century and later. 